\title{
DIALECTICS OF CONTEMPORARY WORLD PROCESSES AND RELATIONS
}

\author{
Milan I. Miljević ${ }^{1, *}$, Vladimir N. Džamić ${ }^{1}$ \\ ${ }^{1}$ Singidunum University, Department for Business Economics, \\ 32 Danijelova Street, Belgrade, Serbia
}

\begin{abstract}
:
Contradictions of nature and the nature of contradictions of post-capitalism, post-socialism and neoliberalism, which are concretized through the world processes and relations of economic crisis, demands humanistic critical examination of theoretical paradigms on which they are based. In the process of theoretical and empirical inquiry, methodological correctness demands to open some important questions: 1) meaning of the concept of dialectics; 2) what does the social science argue about contemporary processes and relations and 3 ) is the dialectics, and if it is, when, the nature of contemporary processes and relations?
\end{abstract}

\section{Key words:}

social theory, scientific method, methodological directions, positivism, dialectics.

"To know is to predict, to predict is to have power."

\section{THE POWER OF DIALECTICS}

A valid critical examination of history and contemporariness of philosophical and scientific thinking makes it clear that dialectics is neither a skill of simple discussion nor a method of dividing and relating concepts, nor the intellectual predominance of contradictions.

Dialectics is a general philosophical theory and method, but not an abstract learning about a method and not a set of rules and not a set of formulae which, as such, are supplied by examples taken from scientific practice. This means that dialectics is a method of radically critical thinking, or "a theoretical infrastructure of critical thinking which sets selfrealization of the man in history as the ultimate aim for itself." (Marković, 1994).
What dialectics refers to is the general structure of human historical practice and its essential aspect - critical thinking. And as a general philosophical method, dialectics cannot be a mere cognitive process of description and analysis of the existing, but the method of determining objectives and means of the human action. If this is so, we ask a question: What actions and what kind of actions? The answer is as follows: The one(s) and of that kind which will be realized based on the following methodical principles:

1. Reality should be grasped as a complex totality, and not as a mere sum of parts, which can be analyzed in isolation. Only such a comprehensive approach reveals possibilities of radical change.

2. Beyond sharp contrasts and dichotomies which conceptual research stems from, mediating examples and cases should be discovered. 
3. The study of synchronous, structural relations should be complemented by the study of diachronic historical relations. Objects can be understood only in light of their origin and future potentials.

4. For the changes to be understood and practically carried out, the conflict of immanent forces and tendencies should be studied, and on the level of thought, internal contradictions of terms should be resolved.

5. Unlike processes in nature, which are subject only to the external mechanical determination, social processes must be observed in light of possible self-determination of the participants.

6. The perspective of transcendence is opened by critical research, which follows the concept of practice. This perspective is no arbitrariness, but an except from the quintessential inner limitations of subjects.

Therefore, dialectics is not only a method of learning but also a method of producing reasonable and humane reality. The production can be based only on the grounds of humanistic criticism of reality seeking optimal possibilities to transcend it, and not its mere negation. In this context the main question dialectics answers to is: How to overcome the world of ordinary life, the familiar, given world, which is fixed, reified, which is received without reflection and criticism, in which human relations are fetishized and practice is reduced to abstract labour and a mere supply? And if this transcendence has to be mediated by thought, how to reach the thought of the true spiritual reproduction and the product of reality, to be held up to a concrete totality, and not be satisfied by an abstract fictional totality and not to end up in oblivion of the true subject creativity, or in absurdity, or in alienated transcendence of alienation only in thought.

It is said in a form of a synthetic conclusion: "Dialectics is concerned with "the thing itself". But "the thing itself" is not an ordinary thing, not even a thing at all. "The thing" philosophy deals with is the man and his position in the universe, or, the same thing expressed in other words: the totality of the world, which the man discovers in history, and the man who exists in the totality of the world." (Kosik, 1968).

Discovering the totality of the world in history occurs through and with the help of three basic concepts of wholeness, based on a certain conception of reality, which "postulate corresponding epistemological principles:

1. atomistic-rationalist view, from Descartes to Wittgenstein, sees wholeness as a totality of the simplest elements or facts;
2. organicistic and organicistic-dynamic view, which formalizes wholeness and expresses the rule and priority of wholeness over the parts (according to Schelling, and Spann);

3. dialectical point of view (according to Heraclitus, Hegel and Marx), which sees reality as a structural unit that develops and creates.

In the twentieth century, there was an attack from two sides on the view of reality as a totality. For empiricists, as well as for existentialists, the world fell apart and ceased to be a totality, it became a mess, whose regulation was up to the subject. Order was brought in the chaos of the world by a transcendental subject or the subjective perspective, for which the totality of the world was broken and made up for by all sorts of subjective horizons."(Kosik, 1968), which are formed (politically, economically, legally, culturally and ideologically) as globalism and regionalism (Draker, 1995). In these modern world processes and relations of globalism, in these pseudo-concretenesses, the power of force and the force of power of military-economic centres see the man only and primarily as an object, which means that in the objective-historical practice of mankind, the prime importance of the man as a subject - as a real historical subject (the practice) is not recognized. That is not even possible because it is a false totality - "bad totality" in which the social reality looms "only in the form of an object, final results and facts, but not subjectively as an objective human practice".

False totality of contemporary globalism and regionalism, unlike globalization and regionalization, where the man is a real historical subject, appears, according to Karel Kosik's researches, "in three basic forms:

1. As an empty totality, which lacks reflection, determination of individual moments and analyses; an empty totality excludes reflection, i.e. the conquest of reality in the form of isolated moments, like it excludes the activity of analytical reason as well. "Namely, every factual and purely analytical approach to reality completely oversees the relevant: that the understanding of a historical fact is determined by the holistic conception of reality and that the relations between ostensibly completely objective items are only the final result of a subjective human activity, which in turn becomes understandable only in the complete historical context. Therefore, science and analytical mind seem likely, particularly today 
when positivism and pragmatism dominate so strongly, to consolidate and rationalize the mystifications already present in reality - about humaneness and democracy of globalism, about the humanity of military "inauguration" of democracy, about Americanization of the world.

It should be said as well that with the theoretical standpoint of the empty totality, one cannot go far in the demystification of reality, in the practical transcendence of reified and fetishized human relations. This is also because this and such totality is a mystification by itself. As such, it does not involve the complex, or multidimensional wealth of reality. Thus, the empty totality is insensitive to details. It is unable to grasp and understand the objective meaning of facts, and consequently to notice new phenomena and tendencies in time. In other words, it actually distorts the full picture of reality and thus it cannot, in a sufficiently concrete way i.e. in an effective way, direct the practice which would transcend the reality in a radical way.

2. "As an abstract totality, in which a formalized whole is opposed to parts and a "higher reality" is attributed to hypostatized "tendencies". Thus understood, the totality lacks genesis and development, a formation of a whole, structuralisation and destructuralisation. The totality is a closed unit." This unit (among other things, globalization as a whole) is built through and with sophisticated procedures and processes of national-socialism which in practice creates neofascism.

The abstract totality has several versions, of which organicism and holism are current. For scientific truth, it should be added that the abstract totality manifests itself in two different ways in modern humanism: (1) as a sharp separation of history from mere facticity, and (2) as a view in which results of science (knowledge of parts) are irrelevant to philosophy (the vision of the whole) but not vice versa: science presupposes philosophy in order to devise its partial truths. In this sense, Mihailo Marković is right when he says that "with the dualism of facticity and history, human empirical reality - the only true reality in which the man actually lives - remains totally banal, emptied of history, whereas history is mystified and becomes "the king on horseback", a transcendental reality which takes place behind people's back" (Marković, 1994).
3. "As a bad totality, in which the actual subject is replaced by a mythologized subject. As other important concepts of materialist philosophy, false consciousness, reification, the relation between a subject and object, lose the dialectical character if isolated, torn out of the materialist theory of history and separated from the concepts, with which they create unity in whose "open system" they only acquire their real significance. Similarly, the category of totality also loses its dialectical character if understood only "horizontally", as a relation between parts and the whole, and if its further organic properties are neglected: its "generic-dynamic" dimension (the creation of a whole and the unity of contradictions) and its "vertical" dimension, which is a dialectics of appearance and essence" (Kosik, 1968).

Therefore, the two dimensions of the bad totality make it bad, and they are: firstly, that the social reality (and within it, a global society) is viewed only as an object and final results, but not subjectively as objective human practice - "the fruits of human activity are separated from the activity itself", and secondly, the man as a real historical subject is replaced by a fetishized subject - impersonal forces independent of people and their activities. "The social reality is not learned as a concrete totality if the man within the totality is observed only and primarily as an object, and in the objective-historical practice of humanity the prime importance of the man as a subject is not recognized. So, it is not about the concreteness or the totality of reality, primarily about completeness or incompleteness of facts, about the volatility and mobility of horizons, but about the basic question: what is reality? If it is a social reality, can the answer to that question be a reduced response to another question: how was human society created? In asking the question which determines what social reality is, in determining how social reality was created", (Kosik, 1968) different views of society and the man - the essence of the difference between dialectics and other theoretical approaches, directions and schools are contained.

\section{POWER AND WEAKNESS OF POSITIVISM}

Positivism is the most influential philosophy in contemporary science, according to which the sole function of science is to describe and explain what exists, and if at least some laws are known, to extrapolate what could probably be. Rising against 
all metaphysical speculative research of social reality, positivism has provided a significant contribution to the constitution of modern social sciences. Its insistence on the facts available to be observed and verified and the demands to replace metaphysical speculations with objective and precise knowledge are built into the foundations of all modern sciences. That is the truth, but it is also true that, according to the positivistic view, all evaluations in terms of needs, feelings, ideals, and ethical and aesthetic criteria - are considered to be essentially irrational. From a scientific point of view, they are insignificant.

In the positivistic view of the role of science in society, it is justified and acceptable to advocate the practical application of its results, for every science, in addition to being purely theoretical, must also have a practical function in a society, if not directly, then at least indirectly (Brdar, 2008). However, what is not acceptable is the positivistic determination that the sole function of science is to find the most appropriate means for achieving the goals set by others, as well as to fetishize the role of empirical facts, hence to unduly reduce the object of scientific research and simplify the cognitive process. The request for the application of scientific results in practice cannot and must not be reduced to the positivistic demand that science should be integrated in the existing order and serve as an effective tool for perfecting, strengthening and stabilizing that order. Such a demand ignores the critically-transforming role of science and reduces it to an apology for the existing order, an ideological tool of social practices of the ruling class.

Facts are the basis of a cognitive process, but it is not founded only on them. Reasonable abstractions are not a less important component of the cognitive process, because their use is often a condition for the discovery of scientific laws, especially in social sciences. Therefore, unacceptable and wrong is the positivistic demand that social phenomena should be explored like natural ones, that their essence should be observed, independently of the subjects and their values and experiences. This demand oversees the specificity of social phenomena: the fact that they are a product of human activity, and they contain human purposes, values, aspirations and experiences, without which scientific knowledge inevitably remains one-sided, external and superficial. Hence, one can say that the basic characteristic of positivism is extremely great distrust of abstractions and theory in general - a belief that truly new knowledge of the world (of contemporary world phenomena, processes and relations) is brought to us only by empirical facts. (Kolakovski, 1972).

Neo-positivism goes a step further from the doctrine of Comte, Hume and Berkeley by connecting empiricism with the methods of modern deductive logic. However, even then (perhaps exactly because of the connection), what is scientifically important and theoretically and empirically current for this theoretical and methodological direction, the philosophy of which is based on skepticism, is the claim that, at best, we can only know individual things and processes which can be directly observed - heard, seen, palpated. For the sake of the truth, it should be said that "modern positivism, compared with old positivism, has made a certain step forward in that it acknowledged creativity and the importance of theoretical thinking, freed it of its absolute dependence on sensory experience and thus explained the increasingly great role it plays in modern science. However, neo-positivism has acknowledged only the organizational and prognostic role of theory in relation to experience; it explicitly denies that, for example, philosophy and mathematics tell us anything about the world and its structure. This agnosticism, which was repeated in various forms through all stages of the previous development of positivism, is one of its most typical characteristics - it is the one point where positivism" (Marković, 1994) and dialectics strongly disagree to the largest extent.

Historicism as a method of understanding, as a theoretical and methodological direction, whose founders were Dilthey and Rickert, provides a significant contribution to overcoming the positivistic unilateralism in the study of social phenomena. The reference of the founders of methods of understanding to the meaningful and valuable dimension of social phenomena is extremely significant for a comprehensive understanding of these phenomena. Max Weber, in regard to Dilthey and Rickert, made an even more positive shift in explaining social phenomena (Veber, 1976). In contrast to their subjectivistic and intuitionalistic conception of understanding, Weber approached understanding as a method of scientific explanation. By setting requirements for a meaningful and especially causal adequacy in understanding social phenomena, he created a cognitive foundation for the causal explanation of social phenomena.

However, the creators of historicism quite unilaterally understood social phenomena, because they reduced them to the mental activity of individuals, 
ignoring their practical and social dimension. Overlooking the practical and social side of human activity, they unduly denied the possibility of a causal explanation of social reality, and thus the possibility of discovering scientific laws, which is the ultimate goal of any science. Due to his nominalistic views of society, Weber reduced the causality mostly to forms of individual and historical causation, and for this reason, his methodological approach does not provide determination of the laws that govern society. Instead of laws, social sciences, he says, should establish typical models of social phenomena, processes and relations.

From the analysis of sociological thought, it is derived that classical sociological theories include: socio-darwinistic theories, individual-psychological theories, collective-psychological theories, and formal-sociological theories.

From the essence of socio-darwinistic theories, it follows that they are unilateral. This is because social phenomena and processes are explained by a more or less mechanical application of the law of survival which governs the organic world. They are thus not applicable for understanding human nature and human society. Even though Gumplović treated social conflicts as natural phenomena, and the state as a natural product that is outside all moral principles of people, he made a significant contribution to the explanation of the class, the state and political parties.

Individual-psychological theories of society, as indicated by their essence, represented a theoretical shift, not only in relation to biologistic but also to positivistic-rationalistic theories. With their theoretical approach, Tarde, Pareto, and especially Weber, have contributed to a comprehensive explanation of the man's individual conduct. Representatives of individual-psychological theories of society, because of their nominalistic views of society, especially Tarde and Pareto, did not discover the quintessence of social phenomena, what is specific for social phenomena, and what separates them from individual psychological phenomena. The man's invention and his tendencies to imitate which Tarde shows, and various residues, or innate feelings, aspirations and inclinations of the man, which Pareto starts with, undoubtedly are significant for people's social lives (Pareto, 1935). However, the diversity of social life, and especially its dynamics, cannot possibly be explained by immutable instincts, feelings and preferences. If one embraces the thesis that these psychological properties of a man are changeable, then the cause of their change must be sought in the society, thus denying the basic starting point of these theories. Weber's theory is more fruitful than Tarde's and Pareto's because it recognizes a certain influence of society on the individual behaviour of the man. This influence is realized through social values involved in the mental interaction of individuals. However, due to the nominalistic understanding of society as a mechanical sum of individuals, Weber's theory cannot explain the dynamics of social events. Weber's interpretation of history as a product of economic, political and ideological, and especially religious factors actually means leaving the baseline individualpsychological point of view.

Durkheim's sociologistic theory of all collectively psychological theories made the greatest contribution to understanding and explaining social life. It convincingly showed that, apart from the consciousness of individuals, there is also a so-called collective consciousness, embodied in collective performances, and that consciousness affects the behaviour of individuals. Durkheim overemphasized the importance of collective consciousness in social life. On the one hand, he completely negated any role of the individual and their (i.e. individual) consciousness in social life, and on the other hand, especially in his later works, he marginalized the importance of the so-called morphological structure, the human population, natural and technical environment, economics and politics in social events. Theoretical shortcomings of his teacher, Marcel Mauss largely managed to eliminate and overcome by his understanding of the man as a total being, as a unity of biological, psychological and social elements and the society as a complete phenomenon, composed of bio-psychological, historical and social factors. The theory of the national spirit of Le Bon (1920) is extremely unilateral and hardly sustainable. He reduces a people or a nation to a natural-spiritualistic entity, thus replacing the scientific approach in the interpretation of the nation with the metaphysical approach. Wundt's theory of social psychology is much more acceptable because he does not see the "soul of the people" outside the "soul of the individual", but treats it as a cultural and psychological phenomenon shaped through the cultural history of a people by a functional connection of individuals based on effects of a common language of myth and religion.

Formalistic sociological theories constitute a significant step forward in explaining social relations and social structure. Namely, by analyzing the impact of various forms of social relations, such as 
conflicts and cooperation, dominance and submission, integration and disintegration, competition and adaptation, etc., on social life they drew scientific attention to processes neglected by other theories, and which realistically exist in all social groups and which are important for all social groups. Separation of forms of social phenomena from their content, which these theories otherwise strive to, is not realistically possible. It is possible only in the sphere of speculation, but not in the real life, in which forms are inseparably linked with the content of social phenomena. It was, after all, apparent to advocates of formal theories, who, in their analysis of social processes, had to rely on psychological, cultural, economic and even biological factors.

From the analysis of the history of development of sociological thought it follows that contemporary sociological theories include: 1. Behavioural theories, 2. Functionalistic theories, 3. Neo-functionalistic theories, 4. Psychological-spiritualistic theories, 5. Critical social theories, 6. Structuralistic theories, 7. Phenomenological theories, and 8 . Theories of industrial and postindustrial society.

1. Behavioural sociological theories made a significant contribution to understanding human behaviour. By treating the man's behaviour as a joint product of his individual consciousness and the environment he lives in, they have managed to overcome weaknesses and unilateralism of both individual psychological, and various collective-psychological theories. The theory of Thomas and Znanjecki (1958), and especially Mill's and Hans's theory of motivation and social structure made a particular contribution to this. However, what behavioural theories have failed to observe are global social systems and structures, which condition the content and character of different social states and events, which, as incentives, influence social behaviour of individuals and groups.

2. Functionalistic theories which see human society as a complex, functional unit of various social, psychological and cultural phenomena and processes, pose a major theoretical breakthrough in the scientific explanation of society. Functionalists, with their understanding of society as a real whole, overcome the weaknesses of nominalistic, individual-psychological theories. At the same time, with the complex understanding of the social structure which does not neglect the man as individual, functionalistic theories largely overcome the weaknesses of various psycho- logical theories which reduce society to a collectively psychological entity. What functionalists do is over-emphasize the static nature of society and integrative relations within it. Malinowski, Brown and Parsons saw society, basically, as a static whole whose parts are harmoniously connected and tightly integrated, thereby ignoring or undervaluing social contradictions, tensions and conflicts that are immanent to every society (Parsons, 1969).

3. "On the whole, theoretical efforts of neo-functionalists - Merton (1979), Coser (1986), and Dahrendorf (1959) - to overcome the weaknesses of the theory of Parsons remained half finished. Albeit they accepted the fact that social conflicts are an integral part of social reality, they failed to discover a deeper connection among conflicts and radical structural changes. Their theoretical evaluation of conflict regulation and the form of structural change shows that they largely remain within the integralist conception of society. It is clear from their attitudes on the plurality of conflicting groups and the conflicts among which there is no possibility of accumulation, and therefore no possibility for a radical and fundamental change of the social structure."

4. Critically assessing the psychological and spiritualist theories we may say that scientifically speaking their baseline is disputable, but apart from that, their contribution to understanding social lives of people is significant. Sorokin's theory of the development of socio-cultural systems bears a strong imprint of spiritualistic view of society and history, because three basic super-systems of meaning, which represent timeless and spaceless ideas, are, to him, the basis of all social phenomena and processes (Sorokin, 1962). However, Sorokin's theory is not entirely idealistic because he still sees empirical socio-cultural systems, the real social reality, as a functional unity of the personality system, social systems and culture to which he gives an ontological primacy.

5. The critical theory of society, in general, has provided a remarkable contribution to the understanding of existential problems of the modern man:

a) Horkheimer (1970), Marcuse (1968), Fromm (1980), and Habermas, with an enthusiastic, lucid but also substantiated critique of the instrumental mind and the modern technical and reified civilization based on it, theoretically broke the naive technocratic belief that scientific and technological development au- 
tomatically brought social progress and man's happiness;

b) With a very cogent analysis of economic and political relations, as well as the spiritual condition of the man in modern industrial civilization, they showed that the man, with the scientific and technological development, managed to conquer nature and to master it, but at the same time, with the inhuman use, he built a reified and alienated world in which he lost his human quintessence - the creative freedom and individuality.

Theoretical efforts in the search for a new society, a new civilization, which would be guided by the human use of modern science and technology and thereby would provide a free and the versatile life of the man, have not been very fruitful. Fromm saw a new, more humane society in the form of humanistic socialism, i.e. humanism applied to industrial society, but he did not offer any theoretical postulates on which the society should be based, nor he theoretically determined its carrier. Habermas sees the future society as a society based on communicative action in which individuals engage in social relationships and exercise free communication based on rational arguments rather than the power such as a utopia.

6. Structuralistic theories of Foucault, Levi Strauss and Althusser undoubtedly represent a contribution to the explanation of society, culture and history (Levi Strauss, 1978). With their theoretical preferences, if nothing else, they draw attention to the uncritical perception, the exaggerated role of the subject, the man in social events and the neglect, or underestimation of the role of objective, structural factors in these events. The emphasis of the subconscious, in the form of an anonymous and faceless opinion (by Foucault), or the universal, objective and impersonal spirit (by Levi Strauss), as the only factor that shapes and explains the social structure and its changes, is difficult to accept because it negates any role of the subject in the socio-historical events. The same is true of Althuser's theory which explains social structure and changes in it with the principle of super-determination. It denies any role of the subject in the social life, for it explains structural social changes with the action of the impersonal principle of super-determination.

7. With the critical assessment of phenomenological theories, it can be concluded that they cannot be completely discarded. It is not necessary, because they can be very productive in understanding social relations in small social groups. Phenomenological theories, despite all efforts, have not given convincing arguments for the denial of the ontological status of social phenomena. There is no valid reason to consider the social world less real than the physical and mental world. On the other hand, its interpretative paradigm with which the constitution of social phenomena and social order is explained is highly formalistic and unilateral. By reducing interaction - the basis of social phenomena to an interpretive component and by binding the interpretation to the radical situationism, ethno-methodologists offer a completely unrealistic image of society. Society, for them, is a set of isolated and unrelated situations which are realized in an absolute vacuum.

8. Although on the track of major social changes brought about by the modern scientific and technological revolution, theories of the industrial and postindustrial society are very bold and still not completely empirically founded. There are indisputable facts, stated by the advocates of the theory of new postindustrial society, that the application of results of the scientific and technological revolution in all modern societies, more or less independent of their political organization, has led to the development of mass production, the general increase in the levels of standards of living, and major changes in the structure of work and the population, particularly working population, which made the social and class structure of society seem more distributed, more dynamic and more open.

Precisely from the empirical point of view it is hard to accept their claims that in a society which is in the process of creation, the property loses its significance, that social conflicts are mitigated or they even disappear and that the new society strives to satisfy higher human needs which lead to the versatile development of the man. Primarily, the entire modern civilization is still based mostly on private ownership. Real socialism, which tends to build new social relations on the negation of private ownership, has experienced a historical crash precisely in recent years, while the shareholder ownership, which is a dominant form of ownership in modern capitalism, is, essentially and consequentially, private property.

The scientific-technological revolution, albeit it contributed to the increase in the standard of 
living of all classes, did not abolish or mitigate social conflicts, on the contrary, the sources, causes and bearers of social conflict were multiplied. In the modern society, as Thurén well perceived, social conflicts do not take place, as before, only in the economic sphere, and between two basic classes, but they spread to the political, ethnical and cultural plan where new bearers of conflict appear. In all modern societies both in the West and the East, as convincingly shown by advocates of the critical theory of society, which Thurén also basically accepts, the man, due to the inhumane use of science and technology, becomes more dependent, less free and more alienated than he used to be.

If in a radical way we take and reinvent a theoretical paradigm of positivism and the -isms based on it, as well as the positivistic view of what science can do (determination of empiristically verifiable facts, setting relatively arbitrary hypotheses, deduction of the results of these hypotheses and acquisition of only those hypotheses which work, which are proved suitable for predicting future experiences), we come to the findings of what it does not do: interpret these hypotheses as expressions of objective, natural or social laws. The reason for this is that the positivistic science considers such interpretations ungrounded, dogmatic, metaphysical, in other words, non-scientific. Therefore, it is not necessary for our practice, for a successful practice of globalism i.e. a successful control of the environment we live in. Likewise, or because of this, it is not difficult to determine in a scientifically valid way that one of the gnoseological roots of modern positivism is a practicistic attitude which refuses to move even a step further from what is enough for the practical egoistic purpose - isn't it a birthplace of kitsch and trash? There is a bare practicism at work and it works though and with the help of globalism. This makes the corporate-ideological roots of positivism even more visible.

Namely, science has suffered a fundamental structural change by becoming completely unphilosophical. The highest object of theoretical speculation is no longer the human welfare (or, more precisely, welfare itself) as it used to be, apart from the speculation itself being understood as the highest form of a good life, but everything is subordinated to the unique practical task of increasing technical knowledge and technical power in order to satisfy the assumed essential interest in a better life in material comfort and abundance. This science is dominated by superficiality, bare pragmatism through and with the help of the scientific kitsch and trash. And what reason is limited to is the world of objectivity, calculatedness, manipulativeness, exact sciences, quantifications, mastering and enslaving the nature, and with it the man as a natural being as well. Namely, the promises of technology, especially the indications of information technologies have turned into a threat, and they are a threat, and not just the physical, both to the man and the nature. Unduly subordination of nature, or its uncontrolled enslaving extends nowadays to the man himself. And it leads and has led to the greatest challenge of human existence - the challenge which has ever grown from its own deeds and actions.

\section{IS DIALECTICS THE NATURE OF CONTEMPORARY WORLD PROCESSES AND RELATIONS?}

The results of scientific analyses point to the existence of principle differences "between thinking which considers reality a concrete totality, i.e. a structural whole which develops and forms, and the viewpoint in which human knowledge can or cannot reach the totality of aspects and facts, i.e. all qualities, relations, processes of reality. Otherwise, the reality is understood as a set of all facts. Since human knowledge can never principally comprise all facts, because additional facts and aspects can always be added, the viewpoint of concreteness or totality is considered to be a mystique. A totality truly does not mean all facts. A totality means: reality as a structured, dialectical whole, in which and from which arbitrary facts (a group of facts, a set of facts) can be rationally understood. To collect all the facts, actually, it does not mean to know the reality; all (piled up) facts are not still a totality. Facts are the knowledge of reality, if they are understood as the facts of a dialectic whole, i.e. if they are unchangeable, indivisible, from no other things derivable atoms, from whose sum the reality is comprised of, but if they are understood as structural parts of a whole. The concrete or a totality are not, therefore, all facts, a set of facts, a set of all aspects, things, relations, because this sum lacks the most important the totality and concreteness. Without understanding of what facts mean, i.e. without understanding that the reality is a concrete totality, which for the knowledge of any fact or a set of facts becomes a meaningful structure, the knowledge of the concrete reality or a mystique or an unknowledgeable thing in itself remains." (Kosik, 1968). 
If the theoretical-methodological principle of dialectic examination of social reality of contemporary world processes and relations wants to be truth-like, a radical critique, it must be a viewpoint of a concrete totality only then in order for dialectics to be the nature of world processes and relations, or a viewpoint of a totality, which understands reality in its internal laws and under superficial and accidental phenomena discovers necessary internal connections, is opposed to the viewpoint of empiricism, which is adherent to the phenomenal and accidental manifestations so it cannot come to the realization of developmental processes of reality. "The viewpoint of totality implies the dialectics of lawfulness and coincidence, inner quintessence and phenomenal sides of reality, parts and the whole, products and production and the like." (Kosik, 1968). What does this mean? Before and above all, it means that every phenomenon, every process and every relation on a local, national, regional and global level can be understood as a moment of a whole. Videlicet, every social phenomenon (economical, political, legal, cultural and spiritual) is a historic fact in so much as it is examined as a moment of a certain whole, only then when it "fulfills a dual role which only makes it a historic fact: if, on the one hand, it defines itself, and on the other, it defines a whole; if a producer is the product at the same time; if what determines is simultaneously the determined; if it discovers something else, and is also deciphered by dint of something else; if through another it obtains its true meaning and at the same time gives meaning to something else. The interdependence and interconnection of a part and the whole at the same time means: isolated facts are abstractions, artificially torn off moments of the whole, which only by fitting into the appropriate whole get concreteness and truthfulness. Also, the whole in which its moments are not distinguished and determined is an abstract, emptywhole."

Therefore, dialectics is not and it does not express the nature of globalism, but its radical critique - it takes the thing in its root. And, for the man, this root is not globalism but the man himself. Globalism is a false totality. And in modern globalism, there is in action and it acts: mystification and false consciousness of people of events - of contemporariness and of the past, hypothesizing and privileging of a whole compared to its parts - the road which "instead to the concrete totality leads to a false totality" where globalism and regionalism represent the true and higher reality, and the existence of reality can exist, which we are witnesses of, "independent of facts, especially those which contradict it. In this formulation - the hypothesized and newly independent whole opposed to facts - a theoretical rationale of subjectivism, which anticipates and forces facts in the name of a higher reality, is derived. The facticity of facts is not the reality of facts, but their fixed superficiality, unilateralism, immobility. The reality of facts is contradictory to the facticity of facts, not because it would be the second-order reality, and so, in this sense the reality independent of facts, but because the internal relation is dynamics and contradiction of the totality with the facts."And what dialectics is and does is the nature of the process of globalization. This is because dialectics ,is not a method of reduction, but a method of spiritual and thoughtful reproduction of reality, a method of development and explication of social phenomena from the practical activity of the historical man."

However, when explaining or understanding current world social processes and relations one has to bear in mind what Kosik does, and that is: "differentiating between systematic and additive knowledge and dialectical knowledge" of a totality. The difference is theoretically and in work operationalized as "basic differences of two different concepts of reality. If reality is a set of facts, human knowledge can be only abstract, systematical and analytical knowledge of abstract parts of reality and the whole of reality is unknowable. Precisely because reality is a structural whole which develops and shapes, the knowledge of one fact or a set of facts becomes knowledge of their place in the totality of the reality. In contrast to the summative and systematic knowledge of rationalism and empiricism, which start from the determined baseline principles in the systematic process of linear addition of further facts, the dialectical thinking starts from the assumption that human knowledge is realized in the spiral motion in which every beginning is abstract and relative. If reality is a dialectical, structured whole, the concrete knowledge of reality, in no way, means a systematical annexation of facts to facts and of knowledge to knowledge, but it is a process of concretization, which goes from a whole to its parts and from parts to a whole, from a totality to antitheses and from antitheses to a totality, and in this, spiral-like advancement of gathering, where all notions come in reciprocal motion and they enlighten one another - the concreteness is achieved. The dialectical knowledge of reality does not leave certain terms untouched in the further flow of learning; it is not the summative systematization of notions, built up on the unchangeable and once and for all acquired essence, but a spiral-like process of 
mutual pervasion and enlightenment of notions, where abstraction (unilateralism and isolation) of the aspects of overcoming in the dialectic, quantitative and qualitative, regressive and progressive collection are present. The dialectic understanding of totality means that the parts are not only in the internal interaction and connection with themselves and with the whole, but that the whole cannot be petrified in the abstraction which stands beyond the parts, because it creates (forms) itself as a whole in the interaction of the parts.

Opinions of knowability and unknowability of concreteness as the knowledge of all facts are based on a rationalistic and empiric idea that learning is done through analytical and summative method, whose assumption is the atomistic idea of reality as a sum of things, processes and facts. Conversely, in the dialectical opinion, reality is understood and presented as a whole, which is not only a sum of relations, facts and processes, but their creation, their structure and genesis as well. The dialectical whole includes the creation of a whole and the creation of unity, the unity of opposites and their genesis." Therefore, dialectics as a critical opinion which tends to comprise the thing itself, i.e. the movements of contemporary globalism and regionalism (the way they are today) must learn their reality, which means that it is not even satisfied with abstract schemes of that and such a reality, but not even with abstract ideas of the same. What the dialectical opinion has to and wants to do is to abolish the ostensible independence of the world of the direct daily touch. "The opinion which breaks pseudo-concreteness in order to get to the concreteness is, simultaneously, a process in which the real world is discovered under the world of ostensibility, behind an outer ostensibility of a phenomenon a law of the phenomenon, behind a visible motion the real internal motion, behind a phenomenon - the essence. What gives the character of pseudo-concreteness to these phenomena is not their existence in itself, but the independence in which the existence occurs. That is why the destruction of pseudo-concreteness, which dialectical thinking must perform, does not discard existence or objectivity of these phenomena, but disrupts their ostensible independence by proving their inference, which contrary to their pretension to independence comes forth with the evidence of their realization."

If a concrete totality is the answer to the question what reality is, i.e. an epistemological principle and methodological postulate, then the dialectics of a concrete totality is a theory of reality and its knowledge as reality. This means that the dialectics of a concrete totality is not "a method of comprising and describing all aspect, features, qualities, relations and processes of reality, but a theory of reality as a concrete totality". What does it further mean? Kosik says: "If reality is understood as concreteness, as a structured whole (which, therefore, is not chaotic at all), which develops (therefore, it is not unchangeable and given once and for all), which is formed (therefore, it is not completely finished and changeable only in parts or their organization), this view leads to certain methodological conclusions, which become a heuristic guide and an epistemological principle for studying, describing, understanding, explaining and evaluating certain themed parts of reality, whether it is physics or literary science, biology or political economy, theoretic problems of mathematics or practical issues of regulating human life and social relations."

The afore mentioned thoughts (results of multidisciplinary research) lead to the conclusion that the concrete totality is a dialectical view of knowing the reality which can be operationalized as:

- A complex process whose moment is the destruction of pseudo-concreteness, i.e. fetishistic and ostensible objectivity of phenomena, and the knowledge of its real objectivity;

- A complex process of knowing the historical character of a phenomenon, in which the dialectics of individual and human in general is shown in a certain way;

- Realizing the objective content and meaning of a phenomenon, its objective functions and historical place within social whole;

- Whole is not hypothesized and does not have primacy over its parts in any way;

- Whole is built to the extent in which the parts are structured and destructured;

- Whole is a unity of opposites - dynamic and always open;

- Whole must be understood not only in the horizontal dimension (regarding the relation to parts) but also in the vertical dimension (regarding the dialectics of a phenomenon and the essence, the general, specific and individual);

- Whole is created by the social production of the man and not the interaction of autonomous structures.

Kosik provides an even better conclusion when he says: "If knowledge has not performed the destruction of pseudo-concreteness, and has not discovered, 
under the ostensible objectivity of a phenomenon, its real historic objectivity and because of that it replaces pseudo-concreteness with concreteness, it becomes a prisoner of the fetishistic understanding whose product is a bad totality. Social reality is here understood as a sum or a totality of autonomous structures which mutually influence each other. The subject disappears or, more precisely, the real subject, the man as an objective and practical subject is replaced with a mythologized, reified, fetishized subject: the autonomous movement of structures." (Kosik, 1968). It appears that this provides an answer to the question whether modern science has performed the destruction of pseudo-concreteness in general, and especially the pseudo-concreteness of contemporary world processes and relations. Consequently our cry for dialectics, for dialectic thinking, for the application of dialectic method only by dint of which facts of contemporary world processes and relations can be deciphered.

\section{REFERENCES}

Brdar, M. (2008) Pouke skromnosti: Karl Poper, otvoreno društvo, nauka i filozofija. Belgrade: Zavod za udžbenike. (in Serbian)

Coser, L. (1986) The Functions of Social Conflict. London: Routledge \& Kegan Paul.

Dahrendorf, R. (1959) Class and Class Conflict in Industrial Society. London: Routledge \& Kegan Paul.
Draker, P. (1995) Postkapitalističko društvo. Belgrade: Grmeč-Privredni pregled. (in Serbian)

From, E. (1980) Zdravo društvo. Belgrade: Rad. (in Serbian)

Horkhajmer, M. (1970) Tradicionalna i kritička teorija. Belgrade: BIGZ. (in Serbian)

Kolakovski, L. (1972) Filozofija pozitivizma. Belgrade: Prosveta. (in Serbian)

Kosik, K. (1968) Dijalektika konkretnog. Belgrade: Prosveta. (in Serbian)

Le Bon, G. (1920) Psihološki zakoni u razvoju naroda. Zagreb: Kompus. (in Croatian)

Levi Stros, K. (1978) Divlja misao. Belgrade: Nolit. (in Serbian)

Marković, M. (1994) Filozofski osnovi nauke, Izabrana dela, Vol. 1. Belgrade: BIGZ. (in Serbian)

Markuz, H. (1968) Čovjek jedne dimenzije. Sarajevo: Veselin Masleša. (in Serbian)

Merton, R. (1979) O teorijskoj sociologiji. Zagreb: Centar društvenih djelatnosti. (in Croatian)

Pareto, V. (1935) The Mind and Society. New York: Dover.

Parsons, T. (1969) Pregled društvenih sistema. In: Parsons T., Šils E., Negel K.D., Pits Dž.R., eds. Teorije o društvu. Belgrade: Vuk Karadžić. (in Serbian)

Sorokin, P. (1962) Social and Cultural Dynamics. New York: Bedminster Press.

Thomas, I., Znanjecky, F. (1958) The Polish Peasant in Europe and America. New York: Basic Books.

Veber, M. (1976) Privreda i društvo. Belgrade: Prosveta. (in Serbian)

\section{DIJALEKTIKA SAVREMENIH SVETSKIH PROCESA I ODNOSA}

\section{Rezime:}

Protivurečnosti prirode i priroda protivurečnosti postkapitalizma, postsocijalizma i neoliberalizma koje se konkretizuju kao svetski procesi i odnosi ekonomske krize zahtevaju humanističko kritičko propitivanje teorijskih paradigmi na kojima su zanovani. U procesu teorijsko-empirijskog propitivanja metodološka korektnost i naučna higijena zahtevaju da u samom otpočinjanju procesa istraživanja ukažemo i pokušamo da validno odgovorimo na sledeća i bitna i aktuelna pitanja: 1) značenje samog pojma dijalektike; 2) šta o savremenim pojavama, procesima i odnosima zbore teorije o društvu, odnosno nauka za koju Hajdeger u Uvodu u metafiziku kaže da je danas u svim svojim granama tehnički, praktički posao dobijanja i prenošenja informacija i 3) da li je, ako jeste kada, dijalektika priroda savremenih svetskih procesa i odnosa?

\section{Ključne reči:}

društvena teorija, naučni metod, metodološki pravci, pozitivizam, dijalektika. 